\title{
Development of bouillon cubes from souari nut pulp: formulation and physicochemical and sensorial evaluations
}

\author{
Desenvolvimento de tempero de pequi na forma de tablete: formulação e avaliação \\ físico-química e sensorial
}

\author{
Érica de Fátima Rodrigues', Lílian de Araújo Pantoja', Mariana Batista Soares², David Lee Nelson², \\ Alexandre Soares dos Santos ${ }^{4 *}$ \\ ${ }^{1}$ Universidade Federal dos Vales do Jequitinhonha e Mucuri (UFVJM), Institute of Science and Technology, Diamantina/MG - Brazil \\ 2Universidade Estadual de Campinas (UNICAMP), Department of Food Science, Campinas/SP - Brazil \\ ${ }^{3}$ Universidade Federal dos Vales do Jequitinhonha e Mucuri (UFVJM), Diamantina/MG - Brazil \\ ${ }^{4}$ Universidade Federal dos Vales do Jequitinhonha e Mucuri (UFVJM), Department of Basic Sciences, Diamantina/MG - Brazil
}

\section{*Corresponding Author}

Alexandre Soares dos Santos, Universidade Federal dos Vales do Jequitinhonha e Mucuri (UFVJM), Department of Basic Sciences, Rodovia MGT 367, km 583, 5000, Alto da Jacuba, CEP: 39100-000,Diamantina/MG - Brazil, e-mail: alexandre.soares@ufvjm.edu.br

Cite as: Development of bouillon cubes from souari nut pulp: formulation and physicochemical and sensorial evaluations. Braz. J. Food Technol., v. 19, e2015054, 2016.

Received: July 02, 2015; Accepted: June 27, 2016

\section{Summary}

The proximate composition and acceptability of bouillon cubes prepared from souari nut pulp flour were evaluated. The whole fruit pulp and formulated bouillon cubes were subjected to an analysis of the total phenolic compounds, protein, lipid, moisture, ash, fibre, total carbohydrate and total energy values. The selected formulations of souari nut bouillon cubes were subjected to a sensory analysis as seasoning for rice preparations, and the physicochemical analysis of the most widely preferred formulation was carried out. The whole souari nut pulp was found to contain $44.4 \%$ moisture, $37.7 \%$ lipids, $2.1 \%$ protein and $10.9 \%$ total carbohydrates, as well as $324 \mathrm{mg}$ of total phenolic compounds per $100 \mathrm{~g}$ of pulp. The souari flour contained $9.8 \%$ moisture. In the sensory tests, the preferred formulation was that containing the highest souari nut flour concentration. This formulation contained $8.4 \%$ moisture, $52.3 \%$ lipids, $3.1 \%$ protein, $19.4 \%$ total carbohydrate, $321 \mathrm{mg}$ of phenolic compounds per $100 \mathrm{~g}$ and a total energy value of $560.7 \mathrm{kcal}$ per $100 \mathrm{~g}$. The souari nut bouillon cubes presented the characteristic colour, taste and aroma of the fruit and an appearance similar to that of commercial bouillon cubes.

Keywords: Caryocar; Bouillon; Seasoning; Spice; Souari nut.

\section{Resumo}

A composição centesimal e a aceitabilidade de um tempero culinário em forma de tablete preparado da polpa de pequi desidratada foram avaliadas. A polpa de pequi integral e os tabletes formulados foram submetidos às determinações dos valores de compostos fenólicos totais, proteínas totais, lipídios, umidade, cinzas, fibra bruta, carboidratos totais e valor energético total. Depois da seleção das formulações para o preparo dos tabletes de pequi, estes foram submetidos à avaliação sensorial como condimento para o preparo de arroz. Na polpa do pequi, foram encontrados $44,4 \%$ de umidade, $37,7 \%$ de lipídeos, 2,1\% de proteínas, 10,9\% de carboidratos totais e $324 \mathrm{mg}$ de compostos fenólicos totais por $100 \mathrm{~g}$. A farinha da polpa de pequi apresentou 9,8\% de umidade. Nos testes sensoriais, a formulação preferida foi aquela com maior quantidade de polpa do fruto na forma de farinha. Esta formulação apresentou 8,4\% de umidade, 52,3\% de gordura, $3,1 \%$ de proteínas, $19,4 \%$ de carboidratos totais, $321 \mathrm{mg}$ de compostos fenólicos por $100 \mathrm{~g}$ e um valor energético total de 560,7 kcal por $100 \mathrm{~g}$. Os tabletes de pequi produzidos mantiveram a cor, o sabor e o aroma característicos do fruto e apresentação similar aos caldos em cubo comerciais.

Palavras-chave: Caryocar; Condimento; Tablete; Tempero; Pequi. 


\section{Introduction}

The souari nut tree, Caryocar brasiliense Camb, is a species endemic to the Brazilian savanna, known as the Cerrado biome. Its fruit is a drupe that can contain up to four putamens. The putamen corresponds to the dispersion unit, consisting of the seed (coated by a thin, brown seed coat) covered by the hard and thorny endocarp and the inner, yellowish mesocarp, which is the edible part of the fruit and surrounds the endocarp (LUZ et al., 2011). The souari fruit has been extensively studied, mainly because of its attractive nutritional composition, which features components such as carotenoids, phenolic compounds, proteins, lipids, carbohydrates and antioxidants (ROESLER et al., 2008; OLIVEIRA et al., 2010; MACHADO et al., 2013). Some authors have evaluated the use of the souari fruit or its oil for the prevention of chronic and degenerative diseases such as cancer and gastric ulcers (LIMA et al., 2007; QUIRINO et al., 2009).

Due to its differentiated flavour and oil content, the souari fruit can be exploited for the preparation of various products such as the manufacture of flour and liquors from the souari pulp and cosmetics, soaps and spices from the oil (PIANOVSKI et al., 2008; OLIVEIRA et al., 2008; SOUZA et al., 2014). One way to facilitate the spread of the souari on the market involves the development of a bouillon cube as proposed by Barbosa et al. (2006). Several bouillon cubes are commercially available for seasoning, such as chicken, beef and bacon. This form of seasoning would promote an increase in the consumption of the souari fruit as a condiment in the off season, as well as during the harvest period.

Bouillon cubes are taste enhancers and are added to foods to augment the taste properties of the food. Bouillon preparations were introduced after the First World War to compensate for the lack of staple foods. The ingredients that may be included in the formulation of a bouillon preparation are salts (sodium chloride and monosodium glutamate), refined hydrogenated vegetable oils, animal fats, bouillon extract, meat extract, yeast extract and vegetables (CAPONIO et al., 2003). The industrial scale manufacturing process for bouillon cubes is very simple. In general, all the dry ingredients are mixed together, followed by mixing/granulation with molten fat and the addition of colouring agents and flavours. This mixture is then cooled, shaped, wrapped and packaged (GUPTA; BONGERS, 2011).

The objective of the present study was to develop a culinary spice using the flour obtained from the dried souari pulp to promote a new taste for bouillon cubes. This objective involved the physical characterization and proximate analysis of the souari fruit, the preparation of the souari pulp flour, the formulation of bouillon cubes containing the flour, the physicochemical characterization of the bouillon cubes, the use of the souari cubes as seasoning for the preparation of rice and the sensory analysis of the rice dish.

\section{Material and methods}

\subsection{Starting material}

The pyrenes of the fruit (seed with pulp), acquired on the local market in Montes Claros, Minas Gerais, Brazil, were used as the starting material. The fruits were obtained by extractive collection from native souari nut trees of the Caryocar brasiliensis species.

\subsection{Physical characterization of souari pyrenes}

A sample of 40 pyrenes weighing $0.83 \mathrm{~kg}$ was randomly selected from a batch of 374 fruits having a total mass of $7.75 \mathrm{~kg}$. The length and diameters of the pyrenes were measured with a digital caliper. The fruits were weighed on an analytical balance and pulped manually using stainless steel knives so that the pulp and seed could be weighed separately. The pulp yield was calculated as the ratio of the total weight of the pulp to the total weight of the fruit and expressed as a percentage.

\subsection{Fruit processing and preparation of the souari flour}

The souari fruits that were spoiled or presented mechanical damage were discarded, and only those that were fit for consumption were used. The fruits were subjected to heat treatment by immersion in boiling water for 10 minutes, followed by fast cooling by immersion in an ice bath to prevent possible enzymatic browning and to reduce the number of natural or contaminant microorganisms. The pyrenes were pulped as described above. The pulp was ground in an industrial blender (METVISA, Type LQ.6) without the addition of water to produce small granules, which were packed in polyethylene bags, weighed, labelled and stored in a freezer at $-18{ }^{\circ} \mathrm{C}$. To produce the dried souari flour, the pulp was thawed and dried in an oven with forced air circulation at $65{ }^{\circ} \mathrm{C}$ for 24 hours, followed by crushing in a meat grinder $\left(\mathrm{N}^{\circ} 8-\mathrm{BOTINI}{ }^{\circledR}\right)$ and passing through a 2-mm-mesh sieve.

\subsection{Pre-tests for the preparation of souari bouillon cubes}

The garlic ( 8 and $16 \%$ ), salt (4, 8 and $12 \%$ ), souari flour (20, 60 and $80 \%)$ and water, as a complement, were combined in a preliminary trial as a starting point for determining the basic formulation for the souari cubes. The response variables observed in this first step were determined by an intra-laboratory sensory analysis with five subjects who considered the dough consistency, characteristic flavour and colour in the choice of the formulations. Other ingredients used in the preparation of the souari cubes were saffron $(0.5 \%)$, vegetable fat 
(3\%), monosodium glutamate $(0.8 \%)$ and dehydrated parsley $(0.3 \%)$.

\subsection{Preparation of the souari bouillon cubes}

After the pre-tests, three formulations were developed by mixing souari flour ( 60,70 or $80 \mathrm{~g})$, salt $(12.0 \mathrm{~g})$, garlic $(12.0 \mathrm{~g})$, vegetable fat $(3.0 \mathrm{~g})$, monosodium glutamate $(0.8 \mathrm{~g})$, saffron $(0.5 \mathrm{~g})$ and dehydrated parsley $(0.3 \mathrm{~g})$. Ten grams of each homogenized mixture was moulded into a cube form. The spice in cube form was wrapped in waxed paper, followed by aluminium foil, and stored at room temperature. The length, width and height of the cubes were measured with the aid of a digital caliper to obtain a dimension similar to that of commercial bouillon cubes.

\subsection{Preparation of rice seasoned with souari bouillon cubes}

The preparation of type 1 rice seasoned with souari cubes involved the cooking of a mixture containing $100 \mathrm{~g}$ of rice, $3 \mathrm{~g}$ of soy oil, $600 \mathrm{~mL}$ of potable water and $20 \mathrm{~g}$ of souari cubes (two $10 \mathrm{~g}$ cubes) in a covered pan for 30 minutes. No other spice was added to complement the flavour. The souari cube was previously dissolved in $60 \mathrm{~mL}$ of water, and the remainder of the water added in $50 \mathrm{~mL}$ portions until the end of the cooking time.

\subsection{Sensory evaluation of souari bouillon cubes as a condiment for rice}

The sensory evaluations of the rice samples seasoned with one of the three formulations of souari bouillon cubes were carried out according to three criteria: preference, acceptability and characteristic profile (appearance, aroma and taste). The acceptability test was carried out using a structured verbal hedonic scale of five points (1- disliked very much, 2- disliked, 3- neither liked nor disliked, 4- liked, 5- liked very much). The characteristic profile test was based on a hybrid nine-point hedonic scale (VILLANUEVA et al., 2005) (Figure 1). The sensory analyses were carried out with the participation of 63 untrained volunteers, 32 male and 31 female from 18 to 60 years old, selected according to their interest in participating in the sensory analysis panel, previously approved by the institutional ethics committee (CEP-UFVJM 115/11). All the panellists were instructed on how to complete the form and the manner in which the test would be carried out. The samples were randomly coded with three-digit numbers and served on disposable plastic plates. Water was served between samples to remove the aftertaste from the previous sample.

\subsection{Physicochemical characterization of the souari pulp and souari cubes}

The souari pulp and the formulation of the souari cube chosen in the sensory analysis were subjected to a physicochemical analysis with respect to the moisture content, ash content, ether extract, total protein, crude fibre, total carbohydrates (Nifext fraction), $\mathrm{pH}$, total soluble solids and total titratable acidity, expressed as citric acid. All of the analyses were carried out in triplicate in accordance with the procedures defined by the IAL (2008). The total phenolic compounds were determined according to the method described by Singleton and Rossi (1965), using 80\% methanol for extraction and gallic acid as the standard. The total energy value (TEV) was calculated according to the method of Merrill and Watt (1973) using the conversion factors of $4 \mathrm{kcal} / \mathrm{g}$ of protein or carbohydrate and $9 \mathrm{kcal} / \mathrm{g}$ of lipid.

\subsection{Statistical analysis}

The data were subjected to an analysis of variance (ANOVA) using the OriginPro version 8 software, and the means of the characteristics evaluated compared by the use of the Tukey test at a $p$ level of 0.05 .

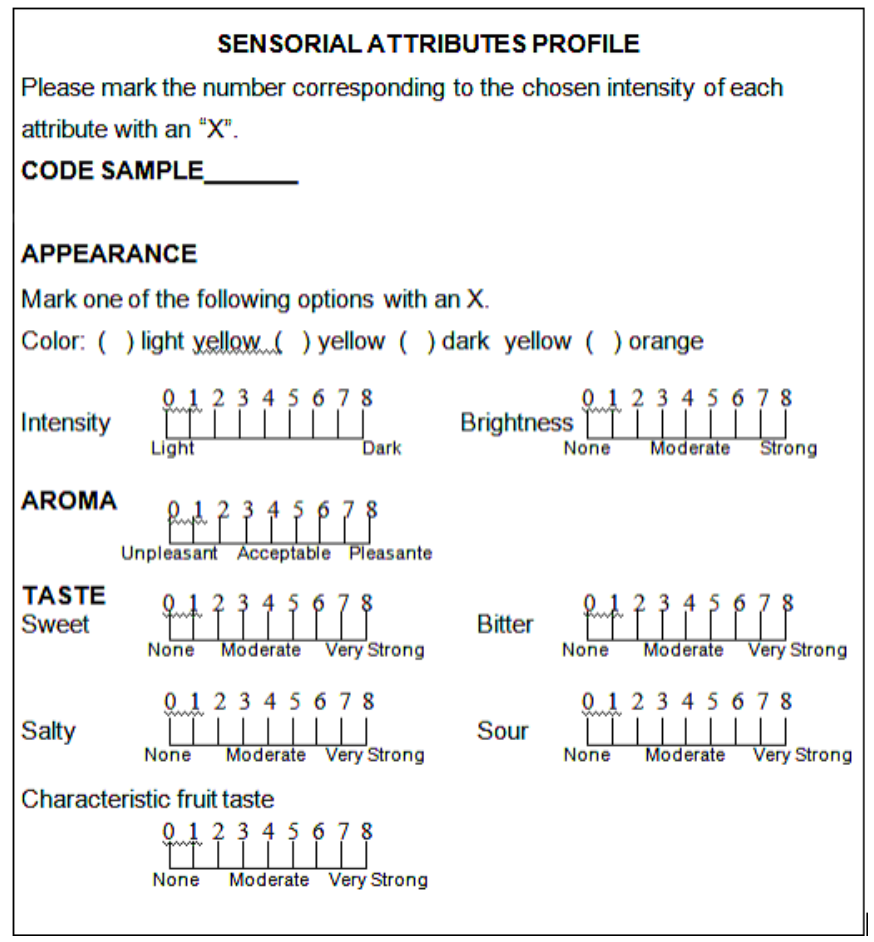

Figure 1. Evaluation card used in the sensory analysis of the characteristic profile (appearance, aroma and taste) of samples of a rice dish seasoned with each of the souari bouillon cube formulations. 


\section{Results and discussion}

\subsection{Physical characterization of the souari fruits}

The fruits had an average mass of $20.66 \pm 3.06 \mathrm{~g}$, and the average mass of the pulp was $6.92 \pm 1.79 \mathrm{~g}$, which corresponded to a pulp yield equal to $33.50 \%$. The seed weighed $13.20 \pm 1.90 \mathrm{~g}$. The average length was $39.05 \pm 1.65 \mathrm{~mm}$, and the diameter was $28.08 \pm 1.24 \mathrm{~mm}$ (Table 1). The results relating to the weight, diameter and length were different from those observed by Machado (2011), who found values of $33.40 \pm 3.72 \mathrm{~g}, 35.38 \pm 3.77 \mathrm{~mm}$, and $48.03 \pm 5.21 \mathrm{~mm}$, respectively. The pulp yield he obtained was $30.58 \pm 2.52 \%$, close to that found in the present work.

\subsection{Physicochemical characteristics of the souari pulp}

The results of the physicochemical analysis of the souari pulp are presented in Table 2. The moisture content of the souari pulp was $44.4 \%$. Ramos and Souza (2011) encountered moisture contents between $25 \%$ and $38 \%$ in the pulp of souari fruits (Caryocar coriaceum) collected in the northeast of Brazil, whereas Ribeiro (2011) observed moisture contents varying from $53 \%$ to $74 \%$ in the pulp of fruits (Caryocar brasiliense) collected in the Brazilian states of Minas Gerais, Goias, Tocantins and Mato Grosso.

The remaining components of the souari pulp are expressed on a dry weight basis (dwb). The results cited

Table 1. Physical characteristics of the souari pyrene ${ }^{1}$

\begin{tabular}{lr}
\multicolumn{1}{c}{ Parameters } & \multicolumn{1}{c}{ Results } \\
Souari mass $(\mathrm{g})$ & $20.66 \pm 3.06$ \\
Pulp mass $(\mathrm{g})$ & $6.92 \pm 1.79$ \\
Seed mass $(\mathrm{g})$ & $13.20 \pm 1.90$ \\
Length $(\mathrm{mm})$ & $39.05 \pm 1.65$ \\
Diameter $(\mathrm{mm})$ & $28.08 \pm 1.24$ \\
\hline
\end{tabular}

${ }^{1}$ Values expressed as means \pm standard deviation. $n=40$.

Table 2. Physicochemical characteristics of the souari pulp

\begin{tabular}{|c|c|}
\hline Constituents & Values \\
\hline Moisture & $44.36 \pm 0.49$ \\
\hline $\operatorname{Ash}(\%)^{*}$ & $1.06 \pm 0.02$ \\
\hline Lipids (\%)* & $67.81 \pm 0.14$ \\
\hline Proteins $(\%)^{\star}$ & $3.81 \pm 0.03$ \\
\hline Total fibre $(\%)^{\star}$ & $7.67 \pm 0.02$ \\
\hline Total carbohydrates $(\%)^{\star}$ & 19.64 \\
\hline Titratable acidity (citric acid \%)* & $0.27 \pm 0.01$ \\
\hline Total soluble solids ( ${ }^{\circ}$ Brix) & 4.49 \\
\hline $\mathrm{pH}$ & $5.77 \pm 0.09$ \\
\hline Phenolic compounds $(\mathrm{mg} / 100 \mathrm{~g})^{\star}$ & $582.31 \pm 0.02$ \\
\hline Total energy value (kcal/100 g)* & 704.17 \\
\hline
\end{tabular}

${ }^{*}$ Quantities are given in percent on a dry weight basis. Values expressed as means \pm standard deviation. $\mathrm{n}=3$. from the literature were also recalculated on a dry weight basis so as to allow for comparison with the results from the present work, since the moisture contents varied widely. The ash content (1.06\%) was similar to the value of $1.08 \%$ reported by Lima et al. (2007). According to Cordeiro et al. (2013), the ash content present in the souari pulp from four locations in the state of Mato Grosso ranged from $0.46 \%$ to $0.57 \%$. They therefore considered the fruit to be an important source of minerals. The ash content found by Ribeiro (2011) in souari pulp from the Brazillian Cerrado varied from $1.4 \%$ to $3.1 \%$. Ramos and Souza (2011) found $2.5 \%$ to $3.2 \%$ ash in souari pulp (Caryocar coriaceum) from the northeast of Brazil.

The souari pulp contained $67.81 \%$ lipids (Table 2). According to Ribeiro (2011), the lipid contents of souari fruits from different regions of the Brazilian Cerrado ranged from $43 \%$ to $70 \%$. According to Lima et al. (2007), the lipid fraction of souari pulp contains predominately unsaturated fatty acids (61.35\%), and of these, oleic acid was found in the highest concentration $(55.87 \%)$. This fact means that the souari pulp is an important source of fatty acids for a healthy diet, since oleic acid is known to cause a reduction in blood lipids, mainly cholesterol, LDL-cholesterol and triglycerides (LOPEZ-HUERTAS, 2010) The high lipid content of the souari pulp contributed to the high energy value found in the present work (704 kcal/100 g dry pulp).

The protein content found in this study was 3.81\%. However, higher protein values for souari pulp were observed by Lima et al. (2007), who observed 5.1\%, and by Machado (2011), who encountered 5.8\%. Ribeiro (2011) observed protein contents from $4.5 \%$ to $6.2 \%$, and Ramos and Souza (2011) found contents that varied from $3.02 \%$ to $3.57 \%$ in souari pulp from the Brazillian Cerrado.

The quantity of dietary fibre found by Lima et al. (2007) was $17.13 \%$. Ribeiro (2011) found fibre contents ranging from $15.9 \%$ to $31.7 \%$ in souari pulp from the Brazilian Cerrado. Ramos and Souza (2011) encountered a mean fibre content of $5.29 \%$ in pulp from the northeast of Brazil. Some of these values are higher than that found in this study (7.67\%). Even so, the souari pulp represents an important source of fibre and, as reported by Mattos and Martins (2000), the use of fibre aids in various functions in the body, such as an improvement of intestinal functions and a reduction in the level of cholesterol.

The amount of total carbohydrates obtained (19.6\%) here was the same as that found by Lima et al. (2007). Oliveira et al. (2010) found 44.2\%, Ramos and Souza (2011) found an average of $57.8 \%$, and Ribeiro (2011) observed carbohydrate contents that varied from $1.1 \%$ to $17.6 \%$.

The total acidity $(0.27 \%$ as citric acid) was consistent with that reported by Sousa et al. (2012), which was $0.28 \%$ as citric acid. Machado (2011) encountered an acidity of $0.14 \%$ as citric acid. The amount of soluble solids found 
in the souari pulp in this work approached that $\left(4.5^{\circ}\right.$ Brix $)$ reported by Sousa et al. (2012).

The $\mathrm{pH}$ of the souari pulp was 5.77, a value close to that found by Machado (2011), who observed a pH equal to 5.38, and below that observed by Arévalo-Pinedo et al. (2010) of 7.36. Thus the souari pulp is classified as a low-acid food ( $\mathrm{pH}>4.5)$.

The concentration of total phenolic compounds found in this work was $63 \%$, higher than that described by Lima et al. (2007) who found $357 \mathrm{mg}$ of total phenolic compounds per $100 \mathrm{~g}$ of souari pulp. Compared with other fruits, the souari pulp evaluated showed 3.9 and 5.4 times more phenolic compounds than red guava (Batiston et al., 2013) and mango (Vasco et al., 2008), respectively. On the other hand, the same souari pulp contained 2.1 and 6.7 times less phenolic compounds than acerola (Batiston et al., 2013) and Andean blackberry (Vasco et al., 2008), respectively. Thus, the souari pulp represents a substantial source of phenolic compounds, which have a close relationship with antioxidant activity (SILVA et al., 2010).

According to Machado (2011), the difference in the values found by different authors for the physicochemical analyses may be related to the degree of maturity of the fruit, the geographical location where it was produced, the weather conditions, planting conditions and post-harvest handling. These factors can affect the chemical composition of the fruit. In general, the results indicate that the souari is a food of high nutritional value because it is rich in fat and represents an important source of protein and dietary fibre.

Table 3. Formulations developed for the preparation of souari bouillon cubes.

\begin{tabular}{lrcr}
\multirow{2}{*}{ Ingredients } & \multicolumn{3}{c}{ Formulation (g) } \\
\cline { 2 - 4 } \multicolumn{1}{c}{ Souari flour } & $\mathbf{1}$ & $\mathbf{2}$ & $\mathbf{3}$ \\
Salt & 60.0 & 70.0 & 80.0 \\
Garlic & 12.0 & 12.0 & 12.0 \\
Vegetable fat & 12.0 & 12.0 & 12.0 \\
Glutamate & 3.0 & 3.0 & 3.0 \\
Saffron & 0.8 & 0.8 & 0.8 \\
Dehydrated parsley & 0.5 & 0.5 & 0.5 \\
\hline
\end{tabular}

\subsection{Development of souari cube formulations and the sensory analysis}

Contrary to the formulation proposed by Barbosa et al. (2006) in his developmental work for a souari Bouillon cube, no starch or soy protein isolate was employed here as supporting ingredients to prepare the souari cube. The intrinsic characteristic of souari flour, with a moisture content of $9.8 \%$, was sufficient for modelling the cubes without any other adjuvant. Of the preliminary formulations tested, one was adopted for the development of three formulations (Table 3) with different quantities of souari flour and fixed quantities of salt, garlic, vegetable fat, glutamate, saffron and dehydrated parsley. These formulations presented a suitable dough consistency and a characteristic flavour and colour. The statistical analysis of the data obtained from the sensory evaluation of the preselected formulations is shown in Table 4. The third formulation differed significantly $(p<0.05)$ from the second with respect to the intensity of the yellow colour shown by the seasoned rice, and it differed from the first formulation with regard to the characteristic flavour of the fruit. The third formulation contained the highest concentration of souari flour (80\%), a fact that justifies the more intensely yellow colour and more striking fruit flavour when compared to the other formulations. As for the other features - brightness, aroma, sweetness, bitterness, and sour and salty tastes - there was no statistical difference at the $p$ level of 0.05 .

The results of the sensory analysis of the rice prepared with the souari cubes were promising for all three formulations. The mean values obtained in the acceptability test for each formulation were higher than the central point (3) in the hedonic scale, which ranged from 1 to 5: 4.3 for formulation 1 and 4.2 and 4.4 for formulations 2 and 3 , respectively. For the 63 panellists who participated in the sensory analysis, the preferred formulation was number 3 , which was preferred by $50.8 \%$ of the panellists, followed by formulations number 1 and 2, with $33.3 \%$ and $15.8 \%$ preference, respectively. This result was consistent with the information collected on the consumption of souari fruit by the panellists; $85.7 \%$ of the panellists who participated in the sensory analysis declared they liked the souari fruit. Of the remaining panellists, $6.35 \%$ said they did not like the souari fruit, and $7.9 \%$ admitted that they had never consumed it. Of the latter, all showed a high degree of acceptance of the rice prepared with the souari bouillon

Table 4. Statistical analysis of the sensory attributes of the three formulations of souari bouillon cubes.

\begin{tabular}{|c|c|c|c|c|c|c|c|}
\hline \multirow{2}{*}{ Formulation } & \multicolumn{2}{|c|}{ Colour } & \multicolumn{4}{|c|}{ Taste } & \multirow{2}{*}{$\begin{array}{c}\text { Characteristic } \\
\text { flavour }\end{array}$} \\
\hline & Intensity & Brightness & Sweet & Bitter & Sour & Salty & \\
\hline 1 & $3.57^{\mathrm{ab}}$ & $3.03^{a}$ & $1.51^{\mathrm{a}}$ & $0.41^{a}$ & $0.52^{a}$ & $2.98^{a}$ & $3.90^{a}$ \\
\hline 2 & $3.40^{\mathrm{b}}$ & $3.16^{a}$ & $1.40^{\mathrm{a}}$ & $0.41^{a}$ & $0.57^{a}$ & $2.95^{a}$ & $4.17^{\mathrm{ab}}$ \\
\hline 3 & $4.19^{a}$ & $3.27^{a}$ & $1.44^{a}$ & $0.38^{a}$ & $0.51^{a}$ & $2.81^{a}$ & $4.57^{b}$ \\
\hline
\end{tabular}

The same letter in the same column indicates there was no significant difference between the means according to the Tukey test $(p<0.05)$. 
cubes. A mean score of 4.2 was given by this group of panellists in the acceptability test.

Rice prepared with the souari bouillon cubes had a yellow colour that could be attributed to the carotenoids present in the souari pulp (RODRIGUES-AMAYA et al., 2008). Furthermore, the saffron present in the composition of the cube may have contributed to the intensification of the natural colour of the fruit, which was directly reflected in the colour of the rice. The means and frequencies of the scores attributed to the sensory characteristics evaluated by the panel for the best formulation are presented in Table 5.

An important fact observed was that $87.3 \%$ of the panellists consumed the fruit occasionally. This fact leads one to believe that the fruit is only consumed during the harvest periods. Thus, the souari bouillon cubes developed in this study would facilitate the consumption of the fruit in off-season periods.

\subsection{Physical and physicochemical characterization of the selected souari bouillon cube formulation}

The souari bouillon cube obtained using the selected formulation presented a yellow colour, a mean weight of $10 \mathrm{~g}$, a length of $30.94 \pm 0.61 \mathrm{~mm}$, a width of $23.59 \pm 0.44 \mathrm{~mm}$, and a height of $10.89 \pm 0.41 \mathrm{~mm}$.
The cubes were easy to mould and were readily soluble in water at room temperature. The weight and format of the cubes were purposely similar to those of commercial bouillon cubes.

The moisture content of the cubes was $8.37 \%$. This fact can be attributed to a loss of moisture from the souari pulp during the process of preparing the flour, and as a result, the concentrations of nutrients in the cubes (Table 6) were higher than those found in souari pulp (Table 3).

The lipid content found in the souari bouillon cubes was $57.1 \%$, which included the lipids from the souari pulp and those that were added in the moulding process. The fat content found in thirty-two samples of bouillon cubes of the most commonly marketed brands analysed by Caponio et al. (2003) ranged between 4.3 and 29.8\%. The unusual lipid content found in the souari bouillon cubes was largely responsible for their high caloric contents $(611.87 \mathrm{kcal} / 100 \mathrm{~g})$. The amount of total fibre determined in the souari cubes was $5.12 \%$. The crude fat and fibre contents in Maggi cubes (vegetable, chicken and beef) and mushroom cubes found by Al-Subhi (2013) presented concentrations ranging between $2.9 \%$ to $4.7 \%$ and $25.9 \%$ to $38.1 \%$, respectively. The total protein and carbohydrate contents found in the souari cubes were $3.39 \%$ and $21.15 \%$,

Table 5. Means and frequencies of the scores awarded by the panel to the sensory characteristics of rice prepared with souari bouillon cubes elaborated with Formulation $3^{*}$

\begin{tabular}{llcccc} 
& \multicolumn{1}{c}{ Characteristics } & Scores & & \multicolumn{3}{c}{ Frequency (\%) } \\
\cline { 3 - 6 } & & (Mean \pm SD) & Values $\leq \mathbf{4}$ & Values = 5 & Values $\geq \mathbf{6}$ \\
Appearance & Brightness & $3.27 \pm 1.55$ & 80.94 & 9.53 & 9.53 \\
Aroma & Characteristic of fruit & $6.37 \pm 1.45$ & 11.11 & 7.94 & 80.95 \\
& Sweet & $1.44 \pm 1.62$ & 96.83 & 3.17 & - \\
Taste & Bitter & $0.38 \pm 0.75$ & 100.00 & - & - \\
& Sour & $0.51 \pm 0.96$ & 100.00 & - & - \\
& Salty & $2.80 \pm 1.29$ & 95.24 & 4.76 & 12.70 \\
\hline
\end{tabular}

*Formulation 3: Souari flour (80.0 g); Salt (12.0 g); Garlic (12.0 g); Vegetable fat (3.0 g); Glutamate (0.8 g); Saffron (0.5 g); Dehydrated parsley (0.3 g).

Table 6. Physicochemical characteristics of souari bouillon cubes prepared using the most highly accepted formulation: Formulation 3 .

\begin{tabular}{|c|c|}
\hline Constituents & Values \\
\hline Moisture & $8.37 \pm 0.14$ \\
\hline Ash $(\%)^{*}$ & $13.26 \pm 0.25$ \\
\hline Lipids $(\%)^{\star}$ & $57.08 \pm 0.22$ \\
\hline Proteins $(\%)^{*}$ & $3.39 \pm 0.11$ \\
\hline Total fibre $(\%)^{*}$ & $5.12 \pm 0.07$ \\
\hline Total carbohydrates $(\%)^{\star}$ & 21.15 \\
\hline Titratable acidity (citric acid \%)* & $0.34 \pm 0.01$ \\
\hline Total soluble solids ('Brix) & 16.4 \\
\hline $\mathrm{pH}$ & $4.86 \pm 0.03$ \\
\hline Phenolic compounds (mg/100 g)* & $350.32 \pm 0.03$ \\
\hline Total energy value (Kcal/100 g)* & 611.37 \\
\hline
\end{tabular}

${ }^{*}$ Quantities are given in percent on a dry weight basis. Values expressed as means \pm standard deviation. $n=3$. 
respectively. These values were, respectively, $30 \%$ and $10 \%$ lower than those found by Al-Subhi (2013) in commercial vegetable cubes. The content of phenolic compounds in the final product $(350 \mathrm{mg} / 100 \mathrm{~g})$ was lower than that of the souari pulp $(582 \mathrm{mg} / 100 \mathrm{~g})$. This difference might be partially the result of dilution of these compounds by the other ingredients in the cubes, in addition to a possible loss during the processing and storage of the raw material. The fixed mineral residue observed in the tablet (13.26\%) was higher than that found in the souari pulp (1.06\%) because of the presence of other ingredients that increased the mineral content of the product, mainly the salt.

\section{Conclusion}

The souari Bouillon cubes developed in this work behaved consistently with that expected for traditional bouillon cubes during the preparation of rice. The formulation with the highest souari concentration was preferred by the panellists in the sensory analysis. The product was rich in fat, had a high energy content and proved to be an important source of phenolic compounds.

\section{Acknowledgements}

The authors gratefully acknowledge the PVNS fellowship provided by CAPES (Edital 06/2012) to D.L. Nelson and financial support furnished by FAPEMIG.

\section{References}

AL-SUBHI, F. M. M. Evaluation of mushrooms broth cube and its compared with Maggi broth cube products in Saudi Arabia. Journal of American Science, Jacksonville, v. 9, n. 5, p. 250-255, 2013.

ARÉVALO-PINEDO, A.; MACIEL, V. B. V.; CARVALHO, K. M.; COELHO, A. F. S.; GIRALDO-ZUÑIGA, A. D.; ARÉVALO, Z. D. S.; ALVIM, T. C. Processamento e estudo da estabilidade de pasta de pequi (Caryocar brasiliense). Ciência e Tecnologia de Alimentos, Campinas, v. 30, n. 3, p. 664-668, 2010. http:// dx.doi.org/10.1590/S0101-20612010000300015.

BARBOSA, R. C. M. V.; POSSIK, P. A.; MONZANI, R.; TEIXEIRA, E.; AMANTE, E. R. Desenvolvimento e análise sensorial do tablete de pequi (Caryocar brasiliense). Revista Ceres, Viçosa, v. 53, n. 310, p. 579-588, 2006.

BATISTON, W. P.; MARUYAMA, S. A.; GOMES, S. T. M.; VISENTAINER, J. V.; SOUZA, N. E.; MATSUSHITA, M. Total phenolic content and antioxidant capacity of methanolic extracts of ten fruits. Acta Scientiarum Technology, Maringá, v. 35, n. 3, p. 581-585, 2013. http://dx.doi.org/10.4025/actascitechnol.v35i3.18533.

CAPONIO, F.; GOMES, T.; BILANCIA, M. T. Bouillon cubes: assessment of the state of degradation of the lipid fraction. Journal of the Science of Food and Agriculture, London, v. 83, n. 13, p. 1331-1336, 2003. http://dx.doi.org/10.1002/jsfa.1544.
CORDEIRO, M. W. S.; CAVALLIERI, A. L. F.; FERRI, P. H.; NAVES, M. M. V. Características físicas, composição químico-nutricional e dos óleos essenciais da polpa de Caryocar brasiliense nativo do Estado de Mato Grosso. Revista Brasileira de Fruticultura, Cruz das Almas, v. 35, n. 4, p. 1127-1139, 2013. http://dx.doi. org/10.1590/S0100-29452013000400024.

GUPTA, S.; BONGERS, P. Bouillon cube process design by applying product driven process synthesis. Chemical Engineering and Processing, Lausanne, v. 50, n. 1, p. 9-15, 2011. http://dx.doi. org/10.1016/j.cep.2010.10.008.

INSTITUTO ADOLFO LUTZ - IAL. Métodos físico-químicos para análise de alimentos. 4. ed. São Paulo: IAL, 2008.

LIMA, A.; SILVA, A. M. O.; TRINDADE, R. A.; TORRES, R. P.; MANCINI-FILHO, J. Composição química e compostos bioativos presentes na polpa e na amêndoa do pequi (Caryocar brasiliense Camb.). Revista Brasileira de Fruticultura, Cruz das Almas, v. 29, n. 3, p. 695-698, 2007. http://dx.doi.org/10.1590/S010029452007000300052.

LOPEZ-HUERTAS, E. Health effects of oleic acid and long chain omega-3 fatty acids (EPA and DHA) enriched milks. A review of intervention studies. Pharmacological Research, London, v. 61, n. 3, p. 200-207, 2010. http://dx.doi.org/10.1016/j.phrs.2009.10.007. PMid: 19897038 .

LUZ, G. R.; RODRIGUES, P. M. S.; MENINO, G. C. O.; COUTINHO, E. S.; NUNES, Y. R. F. Caracterização física de frutos e putâmens e taxa de ataque por Carmenta sp. a pequizeiros (Caryocar brasiliense Camb.) no norte de Minas Gerais. Revista Brasileira de Fruticultura, Cruz das Almas, v. 33, n. 3, p. 746-756, 2011. http://dx.doi.org/10.1590/S0100-29452011005000088.

MACHADO, M. T. C. Concentração de extratos de pequi (Caryocar brasiliense Camb) por nanofiltração. 2011. $134 \mathrm{f}$. Dissertação (Mestrado em Engenharia de Alimentos) - Faculdade de Engenharia de Alimentos, Universidade Estadual de Campinas, Campinas, 2011.

MACHADO, M. T. C.; MELLO, B. C. B. S.; HUBINGER, M. D. Study of alcoholic and aqueous extraction of pequi (Caryocar brasiliense Camb.) natural antioxidants and extracts concentration by nanofiltration. Journal of Food Engineering, Essex, v. 117, n. 4, p. 450-457, 2013. http://dx.doi.org/10.1016/j.jfoodeng.2012.12.007.

MATTOS, L. L.; MARTINS, I. S. Consumo de fibras alimentares em população adulta. Revista de Saude Publica, São Paulo, v. 34, n. 1, p. 50-55, 2000. http://dx.doi.org/10.1590/S003489102000000100010. PMid:10769361.

MERRILL, A. L.; WATT, B. K. Energy values of foods: basis and derivation. Washington: ARS United States Department of Agriculture, 1973. (Agriculture Handbook 74).

OLIVEIRA, M. E. B.; GUERRA, N. B.; BARROS, L. M.; ALVES, R. E. Aspectos agronômicos e de qualidade do pequi. Fortaleza: Embrapa Agroindústria Tropical, 2008. 32 p. (Documentos 113). 
Available at: <http://www.infoteca.cnptia.embrapa.br/infoteca/ bitstream/doc/426706/1/Dc113.pdf.> Accessed on: 09 apr. 2015.

OLIVEIRA, M. E. B.; GUERRA, N. B.; MAIA, A. H. N.; ALVES, R. E.; MATOS, N. M. S.; SAMPAIO, F. G. M.; LOPES, M. M. T. Características químicas e físico-químicas de pequis da Chapada do Araripe, Ceará. Revista Brasileira de Fruticultura, Cruz das Almas, v. 32, n. 1, p. 114-115, 2010. http://dx.doi.org/10.1590/ S0100-29452010005000030.

PIANOVSKI, A. R.; VILELA, A. F. G.; SILVA, A. A. S.; LIMA, C. G.; SILVA, K. K.; CARVALHO, V. F. M.; DE MUSIS, C. R.; MACHADO, S. R. P.; FERRARI, M. Uso do óleo de pequi (Caryocar brasiliense) em emulsões cosméticas: desenvolvimento e avaliação da estabilidade física. Brazilian Journal of Pharmaceutical Sciences, São Paulo, v. 44, n. 2, p. 249-159, 2008. Available at: <www. scielo.br/pdf/rbcf/v44n2/a10.pdf.> Accessed on: 09 apr. 2015.

QUIRINO, G. S.; LEITE, G. O.; REBELO, L. M.; TOMÉ, A. R.; COSTA, J. G. M.; CARDOSO, A. H.; CAMPOS, A. R. Healing potential of Pequi (Caryocar coriaceum Wittm.) fruit pulp oil. Phytochemistry Letters, Amsterdam, v. 2, n. 4, p. 179-183, 2009. http://dx.doi.org/10.1016/j.phytol.2009.06.002.

RAMOS, K. M. C.; SOUZA, V. A. B. Características físicas e químico-nutricionais de frutos de pequizeiro (Caryocar coriaceum Wittm.) em populações naturais da região Meio-Norte do Brasil. Revista Brasileira de Fruticultura, Cruz das Almas, v. 33, n. 2, p. 500-508, 2011. http://dx.doi.org/10.1590/S010029452011005000072.

RIBEIRO, D. M. Propriedades físicas, químicas e bioquímicas de pequi (Caryocar brasiliense Camb.) de diferentes regiões do cerrado. 2011. 64 f. Dissertação (Mestrado em Nutrição) Programa de Pós-Graduação em Nutrição Humana, Universidade de Brasília, Brasília, 2011. Available at: <http://repositorio.unb. br/bitstream/10482/9962/1/2011_DeboraMeloRibeiro.pdf.> Accessed on: 09 apr. 2015.

RODRIGUES-AMAYA, D. B.; KIMURA, M.; AMAYA-FARFAN, J. Fontes brasileiras de carotenóides: tabela brasileira de composição de carotenóides em alimentos. Brasília: Ministério do Meio Ambiente, 2008. Available at: <www.mma.gov.br/ estruturas/sbf.../89_publicaca009032009113306.pdf.> Accessed on: 09 mar. 2015.

ROESLER, R.; CATHARINO, R. R.; MALTA, L. G.; EBERLIN, M. N.; PASTORE, G. Antioxidant activity of Caryocar brasiliense (pequi) and characterization of components by electrospray ionization mass spectrometry. Food Chemistry, London, v. 110, n. 1, p. 711-717, 2008. http://dx.doi.org/10.1016/j.foodchem.2008.02.048.

SILVA, M. L. C.; COSTA, R. S.; SANTOS, A. S.; KOBLITZ, M. G. B. Compostos fenólicos, carotenóides e atividade antioxidante em produtos vegetais. Semina: Ciências Agrárias, Londrina, v. 31, n. 3, p. 669-682, 2010. http://dx.doi.org/10.5433/16790359.2010v31n3p669.

SINGLETON, V. L.; ROSSI, J. A. Jr. Colorimetry of total phenolics with phomolybdic-phosphotungstic acid reagents. American Journal of Enology and Viticulture, Davis, v. 16, n. 3, p. 144-158, 1965.

SOUSA, F. C.; SILVA, L. M. M.; SOUSA, E. P.; LIMA, A. K. V. O.; FIGUEIREDO, R. M. F. Parâmetros físicos e físico-químicos da polpa de pequi. Revista Verde, Jaboticabal, v. 6, n. 1, p. 12-15, 2012. http://dx.doi.org/10.1590/S0100-29452013000400024.

SOUZA, J. P.; ALVES, R. E.; BRITO, E. S.; LUCENA, M. N. G.; RUFINO, M. S. M. Estabilidade de molho de pequi (Caryocar coriaceum Wittm) armazenado à temperatura ambiente. Revista Brasileira de Fruticultura, Cruz das Almas, v. 36, n. 2, p. 425-432, 2014. http://dx.doi.org/10.1590/0100-2945-127/13.

VASCO, C.; RUALES, J.; KAMAL-ELDIN, A. RUALES, J.; KAMALELDIN, A. Total phenolic compounds and antioxidant capacities of major fruits from Ecuador. Food Chemistry, London, v. 111, n. 4, p. 816-823, 2008. http://dx.doi.org/10.1016/j.foodchem.2008.04.054.

VILLANUEVA, N. D. M.; PETENATE, A. J.; DA SILVA, M. A. A. P. Performance of hybrid hedonic scale as compared to the traditional hedonic, self-adjusting and ranking scales. Food Quality and Preference, Barking, v. 16, n. 8, p. 691-703, 2005. http://dx.doi.org/10.1016/j.foodqual.2005.03.013. 